\title{
Cyclical Behavior of Concrete-Encased Composite Frame Joints with High Strength Concrete
}

Lei Zeng, Zhenkun Cui, Yunfeng Xiao, Siqian Jin, and Yuanyuan Wu

School of Urban Construction, Yangtze University, Jingzhou 434023, China

Correspondence should be addressed to Lei Zeng; zenglei@yangtzeu.edu.cn

Received 28 April 2015; Accepted 2 July 2015

Academic Editor: Stefano Sorace

Copyright @ 2015 Lei Zeng et al. This is an open access article distributed under the Creative Commons Attribution License, which permits unrestricted use, distribution, and reproduction in any medium, provided the original work is properly cited.

\begin{abstract}
This paper presents an application of high strength concrete to concrete-encased composite frame building based on an experimental program. The work emphasized joints behavior under reverse cyclic loading caused by earthquakes to provide information for seismic design. To investigate the internal mechanisms and seismic performance, cyclic loading tests were carried out on five half-scale interior joints. Two design variables were addressed in the research: concrete strength and axial column load. Frame joints performance including crack pattern, failure mode, deformation, ductility, strain distribution, and energy dissipation capacity was investigated. It was found that all joint specimens behaved in a manner with joint panel shear failure. Using high strength concrete increased the joint strength and had relatively little effect on the stiffness and ductility. The axial column load helped the joint strength by better mobilizing the outer part of the joint, but it had an obvious influence on the ductility and energy-dissipating capacity, which can be improved by providing enough transverse reinforcement. A typical crack pattern was also provided which can well reflect mechanical character and damage process. This research should contribute to the future engineering applications of high strength concrete to concrete-encased composite structure.
\end{abstract}

\section{Introduction}

Concrete-encased composite structure, as a typical kind of composite structure, is defined as a construction in which both steel and concrete materials are effectively combined to maximize the structural and economic advantages of each material. Concrete-encased composite structure possesses a smaller sectional dimension, higher load-carrying capacity, and more excellent seismic behavior compared with reinforced concrete structures, which has been widely used in superhigh building structures and large-span structures especially in the US [1], China [2], and Japan [3].

Over the past years, various innovations have been developed for concrete-encased composite structure. One clear trend has been the increased use of concrete material with high strength and high performance [4-8]. The introduction of high strength concrete solved a lot of problems in security and endurance because of its high strength, high modulus of elasticity, good endurance, and excellent abrasion resistance, but brittleness hinders its application to engineering structures [9-12].
One important research need aroused by the high strength concrete relates to beam-column joints. Joints between beams and columns are potentially the most critical and possibly the least understood parts of the structural frame. Several elements of the structure meet at a joint, and the combination results in a complex behavior that the joint is at a multiple spindle stress condition under the interaction of bending, shear, and axial loads by adjacent members. Many experiments have been carried out to study the strength and deformation and provide data for developing design equations. The related experiments include concrete-encased steel composite beam to steel column joints [13], composite beam to concrete-filled steel tubular column joints [14], reinforced concrete beam-column joints strengthened with FRP systems [15], beam-column joints with recycled concrete aggregates [16], and steel reinforced concrete column-steel truss beam hybrid joints [17]. Based on the experimental results, design guidelines for composite construction are provided in the ACI code [18], the AISC specification [19], the JGJ specification [20], and the AIJ-SRC code [21]. However, 
a better understanding of the joint behavior has not been yet achieved because of the inherent complexity of the internal mechanisms. In particular, influences of various factors on the joint behavior, such as different joint details, concrete strength, and axial column load, have also been suggested as further research topics. In addition, high strength concrete possesses brittleness and differs with normal concrete in materials, mix proportions, production technology, and bond performance. The influences on joint behavior and corresponding countermeasures have been the important issues to be further studied.

This paper presents an experimental program on the behavior of composite joints with high strength concrete, under constant axial column compression and cyclic loads. The work emphasizes the joint behavior under reverse cyclic loading caused by earthquake to provide information for seismic design. The effects of high strength concrete and axial column load are studied through the following items: failure pattern, crack pattern, load-displacement curves, strain distribution, ductility capacity, and energy dissipation capacity. These results can be used to calibrate numerical models and to validate simplified methods included in codes.

\section{Experimental Program}

2.1. Test Specimens. This research program involved the testing of five interior half-scale beam-column joint specimens. The prototypes were taken from a typical component between the inflection points in a concrete-encased frame structure (see Figure 1). All specimens were designed to fail within its joints. The geometric and the cross section details of the specimens were designed (see Figure 2). The column and beam section dimensions of all specimens were $240 \times$ $200 \mathrm{~mm}$ and $160 \times 280 \mathrm{~mm}$, respectively.

The experimental program is designed to investigate the following variables that may affect the strength, deformation, and seismic performance of the joints (see Table 1 ).

(1) The design axial column load ratio is $\left(n=N / f_{c} b h\right)$, where $N$ was the axial load applied, $b$ and $h$ were the width and depth of the cross section, and $f_{c}$ refers to compressive strength of concrete. The nominal axial column load ratio is also calculated by $n_{0}=N /\left(A_{c}+\alpha_{E} A_{s}\right)$, where $A_{c}$ and $A_{s}$ were the area of concrete and steel section and $\alpha_{E}$ was the ratio of modulus of elasticity of steel and concrete.

Specimens J-1 and J-2 were tested with axial compression load of $750 \mathrm{kN}$ and $1500 \mathrm{kN}$, which corresponds to about $20 \%$ to $40 \%$ of design compressive strength of the concreteencased column. The magnitude represents a reasonable working compressive stress level for typical structures. Specimens J-3, J-4, and J-5 were tested with axial compression load of $2250 \mathrm{kN}, 2750 \mathrm{kN}$, and $2750 \mathrm{kN}$, which represents an ultimate compressive stress level.

(2) An important factor concerned in design is the brittle nature of high strength concrete compared to ordinary strength concrete. High strength concrete, with a strength ranging from $79.82 \mathrm{MPa}$ to $109.54 \mathrm{MPa}$, has been used to investigate the influence on deformation capacity and seismic resistance of joints.
TABLE 1: Design parameter of beam-column assemblies.

\begin{tabular}{lccccc}
\hline Parameter & $\mathrm{J}-1$ & $\mathrm{~J}-2$ & $\mathrm{~J}-3$ & $\mathrm{~J}-4$ & $\mathrm{~J}-5$ \\
\hline Concrete strength grade & $\mathrm{C} 80$ & $\mathrm{C} 80$ & $\mathrm{C} 80$ & $\mathrm{C} 100$ & $\mathrm{C} 60$ \\
Design axial compression ratio & 0.2 & 0.4 & 0.6 & 0.6 & 0.6 \\
Nominal axial compression ratio & 0.19 & 0.38 & 0.56 & 0.52 & 0.55 \\
Axial compression load $(\mathrm{kN})$ & 75 & 150 & 225 & 275 & 275 \\
\hline
\end{tabular}

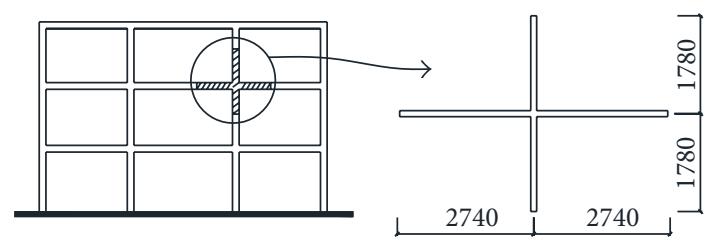

FIGURE 1: Description of prototype model.

2.2. Material Property. The proportions of different mixing substances in the concrete were determined based on the information available from JGJ/T 281-2012 (see Table 2) [22]. To improve the workability, a superplasticizer was mixed with the concrete. The maximum size of coarse aggregate is $13 \mathrm{~mm}$, which was tiny enough to place concrete into the congested joint region.

All specimens were tested at 28 days. Three cylinders $(150 \times 300 \mathrm{~mm})$ were tested to determine the average concrete axial compressive strength and modulus of elasticity for each specimen, and three cubes $(150 \times 150 \times 150 \mathrm{~mm})$ were tested to determine the average concrete cube compressive strength. Thus, the concrete properties were measured (see Table 2).

The encased structural steel used in the specimens was I-shaped hot-rolled structural steel. The longitudinal bar used was $12 \mathrm{~mm}$ in diameter and deformation. Deformation bars of $8 \mathrm{~mm}$ in diameter were used as hoop reinforcement. To determine the average values of the steel mechanical properties, three pieces were tested following GB/T 228.12010 for each one [23]. The results of the characterization tests are shown in Table 3.

2.3. Test Set-Up and Test Procedure. A schematic view of the test set-up and loading system is shown in Figure 3. Horizontal load applied at the column end simulated shear at inflection point which occurs in frames under horizontal loading where applicable, and the vertical load at the end of column induces the axial column load that simulated the column load caused by gravity in practical engineering. The specimens were loaded by a horizontal actuator which applied reverse cyclic forces to the column while a constant compression load was applied by the vertical actuator. The horizontal actuator has a capacity of $500 \mathrm{kN}$ with a $150 \mathrm{~mm}$ stroke and the vertical actuator has a capacity of $1800 \mathrm{kN}$ with a $100 \mathrm{~mm}$ stroke; both are servocontrolled. A force transducer and a displacement transducer were attached to each actuator to measure the applied load and displacement. Each actuator was operated independently in closed-loop displacement control through a microcomputer, a system through which the incremental displacement as small as $0.0025 \mathrm{~mm}$ could be applied to the actuators. 


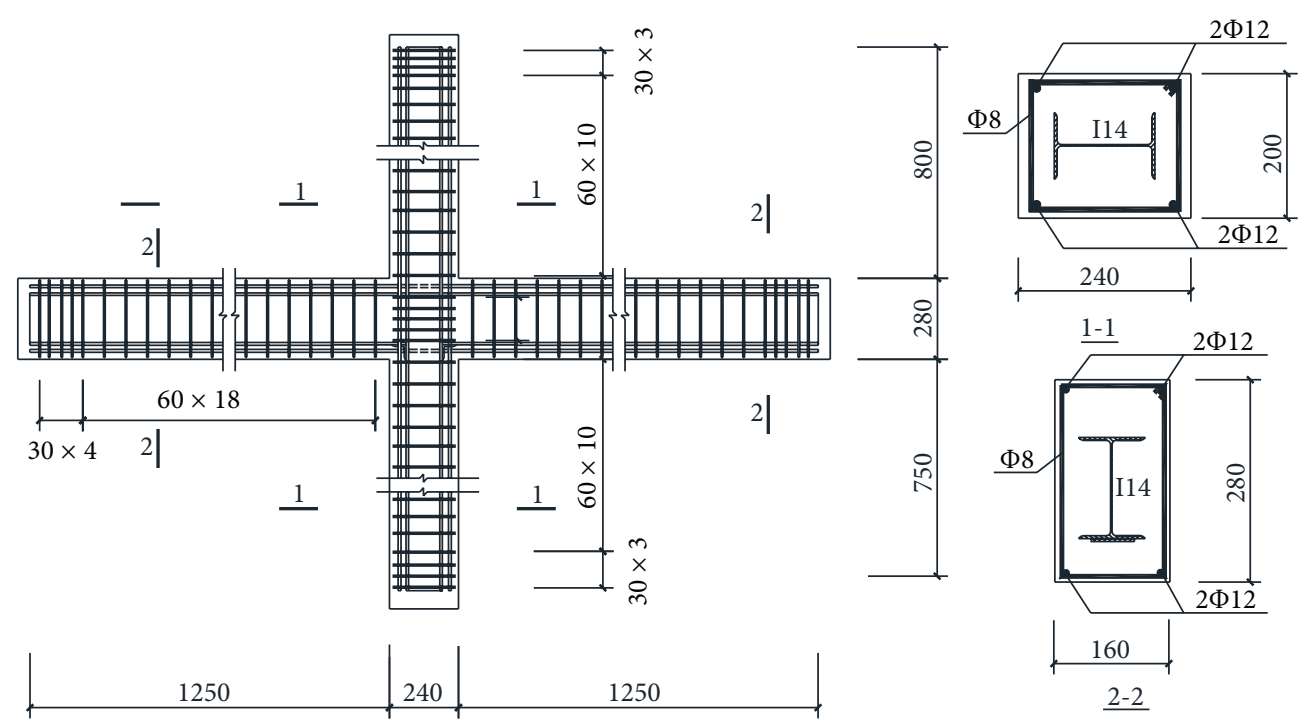

FIGURE 2: Cross section and distributed steel of beam-column assemblies.

TABLE 2: Concrete mix properties and strength.

\begin{tabular}{|c|c|c|c|}
\hline $\begin{array}{l}\text { Design strength } \\
\text { grade }\end{array}$ & C60 & C80 & C100 \\
\hline $\begin{array}{l}\text { Water cementitious } \\
\text { ratio }\end{array}$ & 0.30 & 0.26 & 0.24 \\
\hline Cement $\left(\mathrm{kg} / \mathrm{m}^{3}\right)$ & 350 & 450 & 450 \\
\hline $\begin{array}{l}\text { Coarse aggregate } \\
\left(\mathrm{kg} / \mathrm{m}^{3}\right)\end{array}$ & 700 & 544 & 510 \\
\hline $\begin{array}{l}\text { Fine aggregate } \\
\left(\mathrm{kg} / \mathrm{m}^{3}\right)\end{array}$ & 1150 & 1156 & 1190 \\
\hline Water $\left(\mathrm{kg} / \mathrm{m}^{3}\right)$ & 150 & 156 & 144 \\
\hline $\begin{array}{l}\text { Superplasticizer } \\
\left(\mathrm{kg} / \mathrm{m}^{3}\right)\end{array}$ & 8 & 12 & 12 \\
\hline Silica fume $\left(\mathrm{kg} / \mathrm{m}^{3}\right)$ & 0 & 30 & 60 \\
\hline Fly ash $\left(\mathrm{kg} / \mathrm{m}^{3}\right)$ & 150 & 120 & 90 \\
\hline $\begin{array}{l}\text { Cube compressive } \\
\text { strength }(\mathrm{MPa})\end{array}$ & 79.82 & 87.89 & 109.54 \\
\hline $\begin{array}{l}\text { Axial compressive } \\
\text { strength }(\mathrm{MPa})\end{array}$ & 68.25 & 78.49 & 95.07 \\
\hline $\begin{array}{l}\text { Modulus of } \\
\text { elasticity (MPa) }\end{array}$ & 41675 & 42042 & 42885 \\
\hline
\end{tabular}

TABLE 3: Materials properties of bars and steel plate.

\begin{tabular}{|c|c|c|c|c|c|}
\hline Material & $\begin{array}{c}\text { Yielding } \\
\text { strength } \\
(\mathrm{MPa})\end{array}$ & $\begin{array}{l}\text { Yielding } \\
\text { strain }\end{array}$ & $\begin{array}{c}\text { Ultimate } \\
\text { strength } \\
(\mathrm{MPa})\end{array}$ & $\begin{array}{l}\text { Ultimate } \\
\text { strain }\end{array}$ & $\begin{array}{c}\text { Elastic } \\
\text { modulus } \\
(\mathrm{GPa})\end{array}$ \\
\hline Ф8 bar & 360 & $1.71 \times 10^{-3}$ & 440 & $2.43 \times 10$ & 210 \\
\hline$\Phi 12$ bar & 380 & $1.81 \times 10^{-3}$ & 490 & $2.65 \times 10^{-3}$ & 210 \\
\hline $\begin{array}{l}\text { Steel } \\
\text { plate }\end{array}$ & 317 & $1.51 \times 10^{-3}$ & 420 & $2.26 \times 10^{-3}$ & 210 \\
\hline
\end{tabular}

According to the loading program, column axial column load was first applied, and then horizontal cyclic load was applied step by step to the estimated yielding load. Because
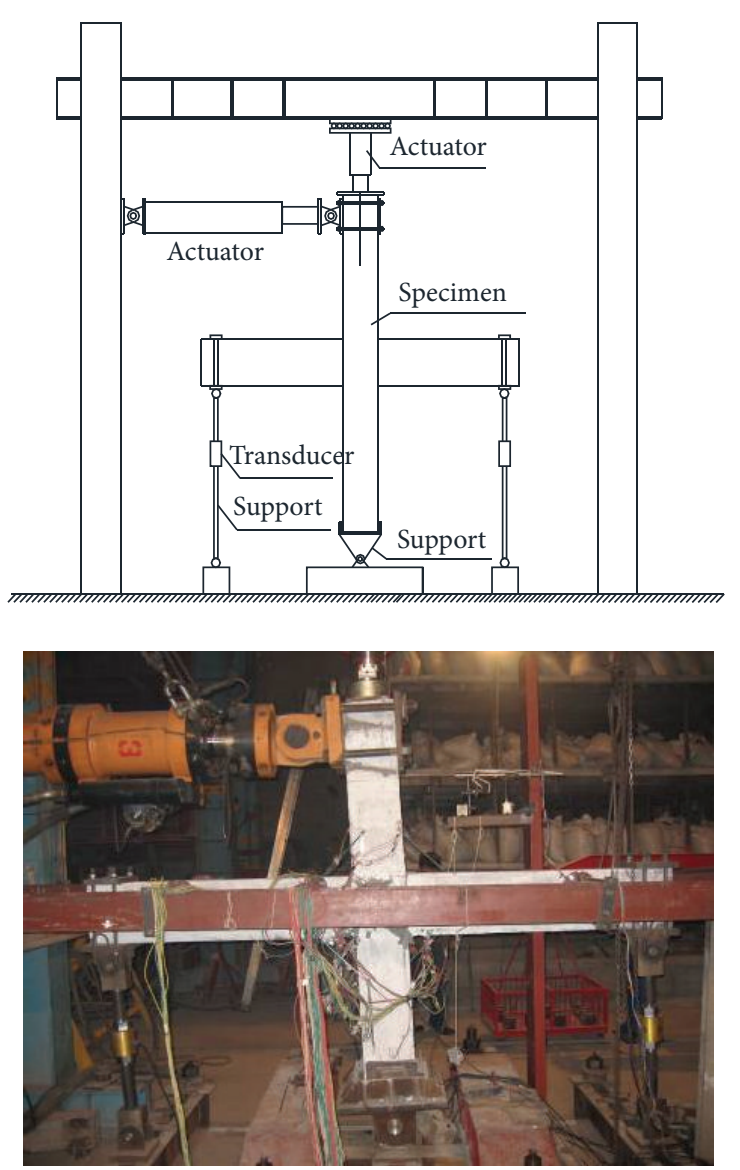

Figure 3: Test set-up and loading system.

specimen J-1 was the first one, small load increment in load control stage was given. The other specimens were loaded to the yielding load in 4 to 6 steps. The last load step circulated for three cycles, current column end deformation was taken 


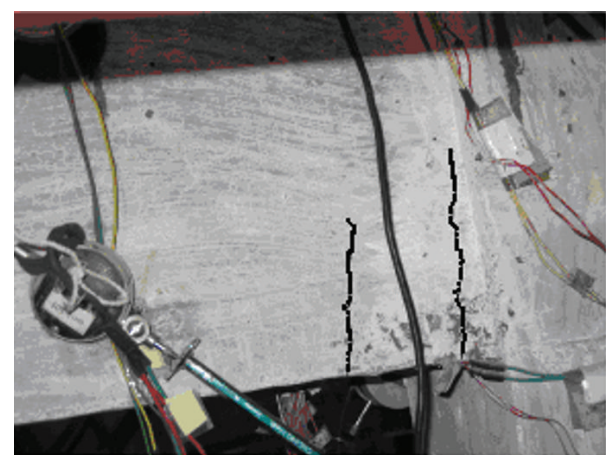

(a) Concrete cracking on beam

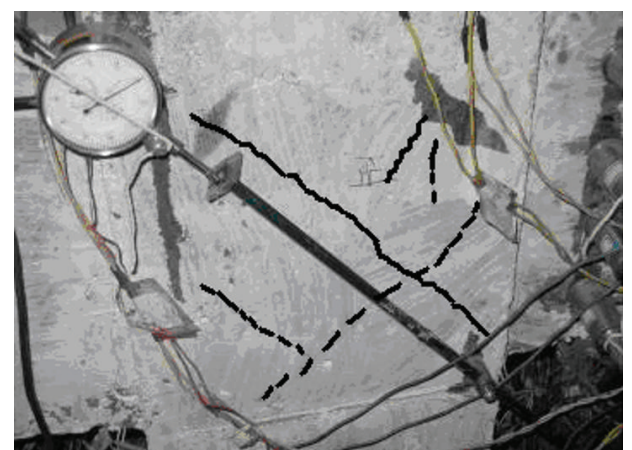

(b) Cracking on panel core zone

FIgURE 4: Experimental phenomenon in elastic stage.

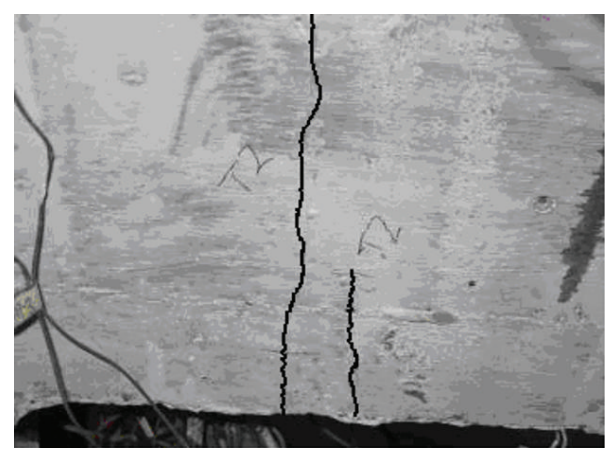

(a) Penetrated crack on beam

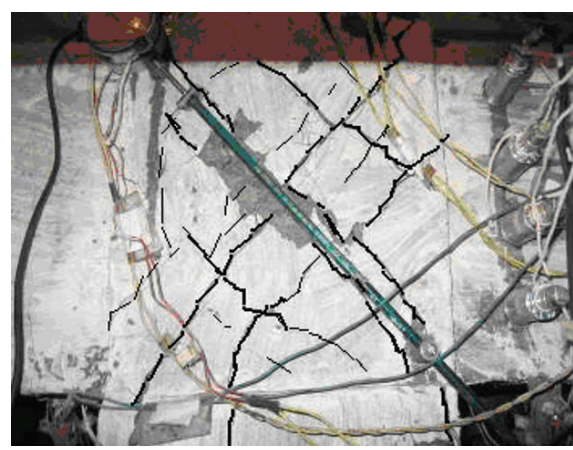

(b) Penetrated crack in panel core zone

FIGURE 5: Experimental phenomenon in cracking stage.

as yielding deformation, and then loading was controlled by deformation. Reverse cyclic column loads were applied until the joint strength decreased to $85 \%$ of the maximum strength.

The test measurement included horizontal deformation at loading point on column end, panel zone rotation, and beamto-column rotation, steel strain, longitudinal bar strain, stirrup strain, load-deformation hysteresis loop, and concrete cracks.

\section{Experimental Results and Discussions}

3.1. General Behavior and Failure Patterns. The failure pattern of all specimens was joint panel shear failure. Each joint specimen went through three stages of elastic stage, cracking stage, and failure stage. Based on the recorded experiment phenomenon, specimens experienced the following characteristic stages successively: beam end concrete cracking vertically, panel core zone concrete cracking, column end concrete cracking, column steel web plate yielding, panel core zone concrete crack penetrating, stirrup yielding, panel core zone concrete spalling, and joints failing. Figures 4, 5, and 6 are the experimental phenomenon of each stage.

3.1.1. Elastic Stage. Test system worked properly and there was no crack detected on column after column axial compression load was applied according to the preplanned level.
The sensing device showed that the beam end support did not bear force. During early loading stages, strain of panel zone steel and concrete increased linearly. When horizontal load reached $20 \mathrm{kN}$ (the first step load), the first vertical crack was detected on the beam end (Figure 4(a)) which extended to 1/4 beam height distance from beam bottom. With the increment of horizontal load, new vertical cracks appeared in the beam end and strain of the beam-column steel increased continuously. Then, the first crack at beam end propagated to joint panel zone. When horizontal load reached $60 \mathrm{kN}$ concrete crack was detected on panel zone along diagonal orientation (Figure 4(b)). This load was cracking load of specimen.

3.1.2. Cracking Stage. Opposite crack appeared in joint panel zone with the increase of horizontal load and the width of crack reached $0.3 \mathrm{~mm}$. Concrete on panel core zone was divided into diamond nub by obvious cross cracks. Flexure cracks in the beam end increased and cut through gradually, but they do not propagate basically. When the load reached $80 \%$ of the maximum load diagonal main concrete crack in joint panel zone cut through and horizontal cracks appeared in the column end. Steel web on panel core zone yielded during an extended process gradually from local part to the whole process. There was no obvious inflexion on loaddisplacement curve. Strain of stirrup on panel core zone increased faster, but it did not reach yielding strain. Strain of 


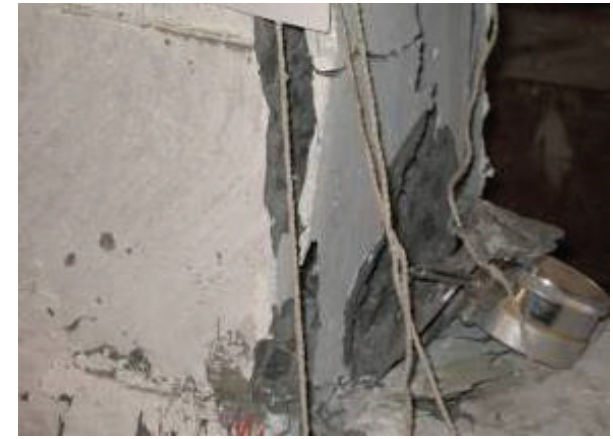

(a) Splitting crack

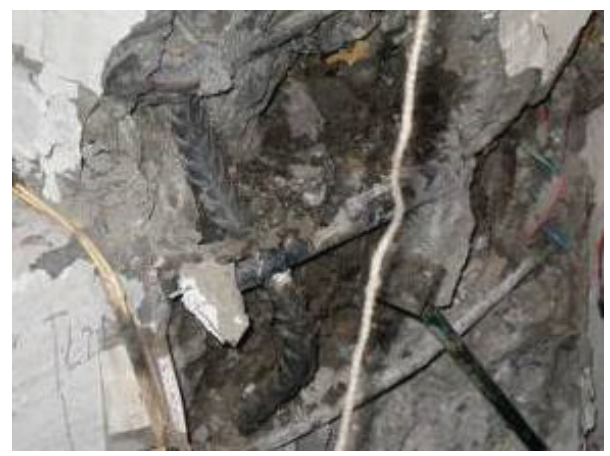

(c) Steel bar bending

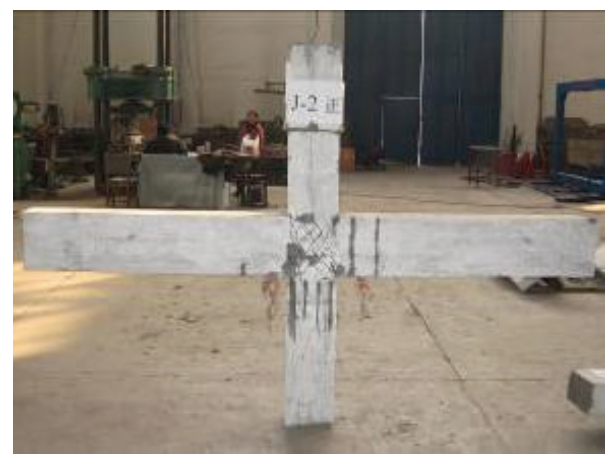

(e) Specimen J-2

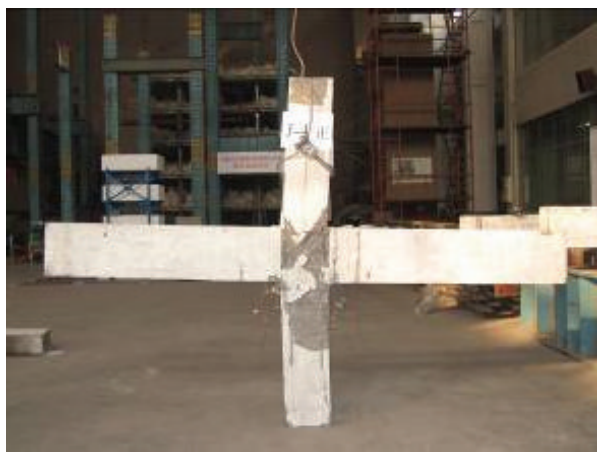

(g) Specimen J-4

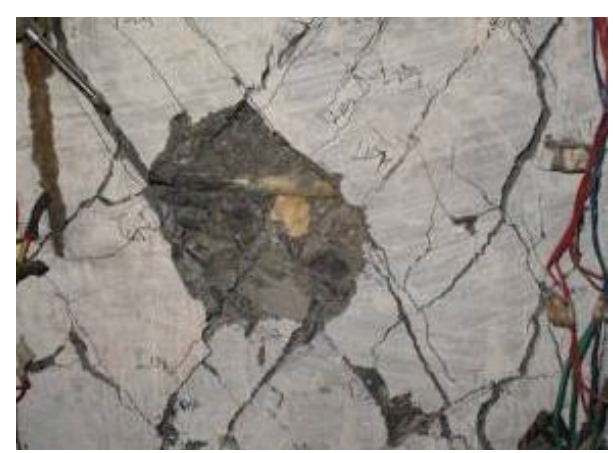

(b) Concrete spalling

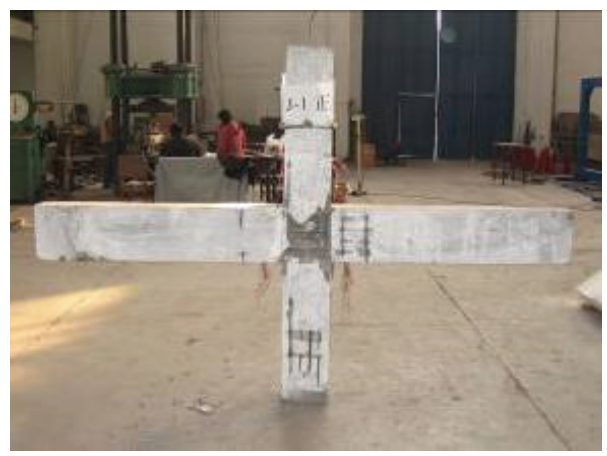

(d) Specimen J-1

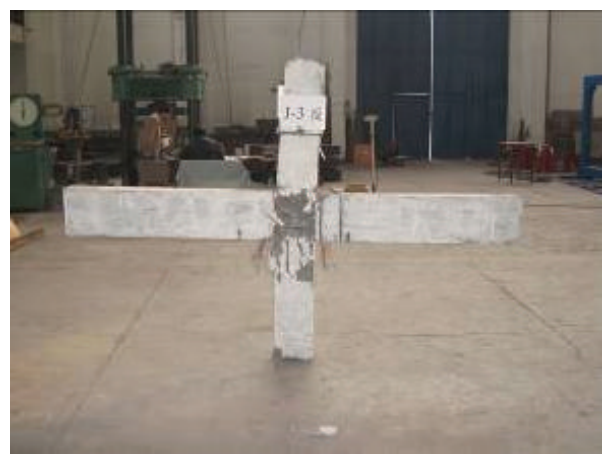

(f) Specimen J-3

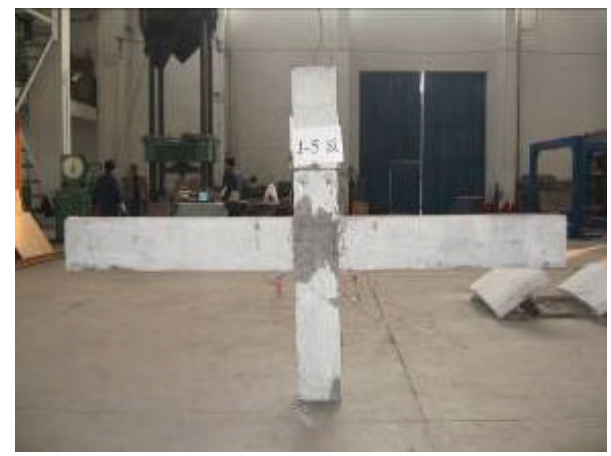

(h) Specimen J-5

FiguRE 6: Experimental phenomenon in failure stage. 
steel flange frame was still small, which could supply more restriction for concrete on panel core zone.

3.1.3. Failure Stage. Steel flange and stirrup yielded with load increasing gradually and were at stage of plastic flow. Due to the strengthening effect of steel and stirrups and aggregate interlock effect between the cracks in the panel core zone, horizontal load continued to increase until it reaches the maximum load values.

After the maximum load, concrete cracks at the panel core zone became certain full cross-shaped cracks, and crack width significantly increased, accompanied by a concrete cracking sound and taut sound of steel bar. Subsequently, the cracks at panel core zone extend to the lower end, the concrete blocks at panel core zone peeled off, and stirrups were exposed. The carrying capacity of the specimen dropped rapidly and declared destruction. The failure picture showed that the bonding between steel and concrete had been destroyed slightly at panel core zone, but local buckling did not happen on steel web because of the sustainability of concrete between the steel flanges.

Under every cycle load and displacement, strength and stiffness degradation of concrete-encased frame joints were less than reinforced concrete joints. Even when the concrete quits working, the steel web can still bear a certain amount of load stably. Compared with steel joints and reinforced concrete joints, the result indicated that concrete-encased frame joints possess better ductile feature and dissipative capacity $[24,25]$.

3.2. Crack Pattern. Crack distributing figure recorded during test is shown in Figure 7. Typical crack patterns were identified in the joints illustrated in Figure 8. Eight types of cracks are identified as follows.

Crack 1: these were vertical cracks occurring at the beam end 15 to $20 \mathrm{~mm}$ apart from column. The cracks were bending cracks under repeated cyclic load. The cracks arose at the $15 \%$ limited load and penetrate gradually.

Crack 2: these were vertical cracks occurring along the column flange plate. The cracks formed simultaneously with other cracks such as Crack 4 and Crack 5 when the joint had moderate damage. The cracks may be caused by bond failure between steel and concrete.

Crack 3: these were diagonal cracks on the sides of the joint caused by shear deformation. The cracks were first observed at load levels of $10 \%$ to $50 \%$ of the maximum strength of the joint, depending on the joint details and presence of axial column load. The load levels at which the first cracks were observed may also be related to the amount of joint deformation, but a clear relation between them could not be drawn from the experimental data. The number and width of cracks seemed directly related to joint damage. As the loading was increased, the number and width of cracks became so many and wide that most of the concrete cover was spalled at the time of failure.

Crack 4: these were inclined cracks which are basically extensions of Crack 4 . The cracks were typically observed when the joint had moderate to severe damage irrespective of the joint failure mode.

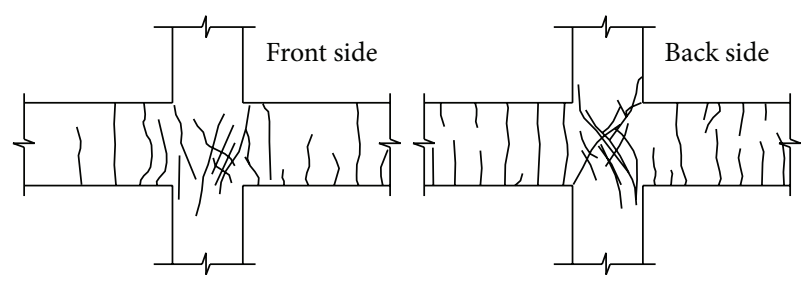

FIGURE 7: Crack distributing figure.

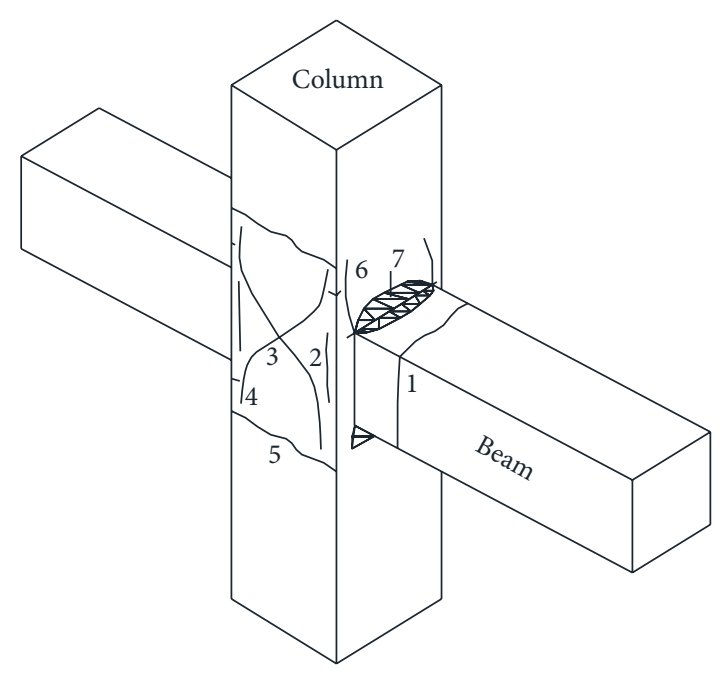

FIgURE 8: Typical crack pattern.

Crack 5: these were horizontal flexural cracks on the column which formed directly over the encased steel. These cracks were initiated at the early stage of loading and were not related to the overall joint failure.

Crack 6: these were inclined cracks initiated from the beam corner. The cracks were caused by bearing stresses above and below the beam. They were initiated when the joint had light to moderate damage.

Crack 7: this was a region of concrete crushing caused by bearing above and below the beam. The degree of concrete crushing was directly related to the overall damage of the joint.

3.3. Deformation. To investigate the contribution of panel zone shear deformation to the total story drift, horizontal deformation at loading point on column end, panel zone rotation, and column-to-beam rotation were measured in the test. Figure 9 shows the devices to test deformation.

As Figure 10 shows, column-to-beam rotation $\phi_{j}$ is the rotation between beam and column axes at the panel zone boundary, which is composed of panel zone rotation $\gamma$ and connection rotation $\phi_{c}$, and it is given by

$$
\phi_{j}=\gamma+\phi_{c} .
$$


TABLE 4: Story drift analysis at yielding, limiting, and failure point.

\begin{tabular}{|c|c|c|c|c|c|c|c|c|c|c|c|c|}
\hline \multirow[b]{2}{*}{ Number } & \multicolumn{4}{|c|}{ Yielding } & \multicolumn{4}{|c|}{ Limiting } & \multicolumn{4}{|c|}{ Failure } \\
\hline & $\begin{array}{c}\Delta_{y} \\
(\mathrm{~mm})\end{array}$ & $\begin{array}{c}\Delta_{\mathrm{pz}} \\
(\mathrm{mm})\end{array}$ & $\begin{array}{c}\Delta_{c} \\
(\mathrm{~mm})\end{array}$ & $\Delta_{\mathrm{pz}} / \Delta$ & $\begin{array}{c}\Delta_{y} \\
(\mathrm{~mm})\end{array}$ & $\begin{array}{c}\Delta_{\mathrm{pz}} \\
(\mathrm{mm})\end{array}$ & $\begin{array}{c}\Delta_{c} \\
(\mathrm{~mm})\end{array}$ & $\Delta_{\mathrm{pz}} / \Delta$ & $\begin{array}{c}\Delta_{y} \\
(\mathrm{~mm})\end{array}$ & $\begin{array}{c}\Delta_{\mathrm{pz}} \\
(\mathrm{mm})\end{array}$ & $\begin{array}{c}\Delta_{c} \\
(\mathrm{~mm})\end{array}$ & $\Delta_{\mathrm{pz}} / \Delta$ \\
\hline $\mathrm{J}-1$ & 19.7 & 4.0 & 15.7 & 0.20 & 55.3 & 7.6 & 47.7 & 0.14 & 76.4 & 33.8 & 42.6 & 0.44 \\
\hline $\mathrm{J}-2$ & 16.3 & 11.3 & 5.0 & 0.69 & 45.4 & 19.3 & 26.1 & 0.43 & 60.6 & 40.3 & 20.3 & 0.67 \\
\hline $\mathrm{J}-3$ & 20.6 & 8.6 & 12.0 & 0.42 & 50.2 & 20.8 & 29.4 & 0.41 & 72.6 & 61.2 & 11.4 & 0.84 \\
\hline$J-4$ & 21.7 & 11.3 & 10.4 & 0.52 & 44.1 & 22.5 & 21.6 & 0.51 & 63.5 & 46.4 & 17.1 & 0.73 \\
\hline $\mathrm{J}-5$ & 18.6 & 7.2 & 11.4 & 0.39 & 45.3 & 14.5 & 30.8 & 0.32 & 73.1 & 48.3 & 24.8 & 0.66 \\
\hline
\end{tabular}

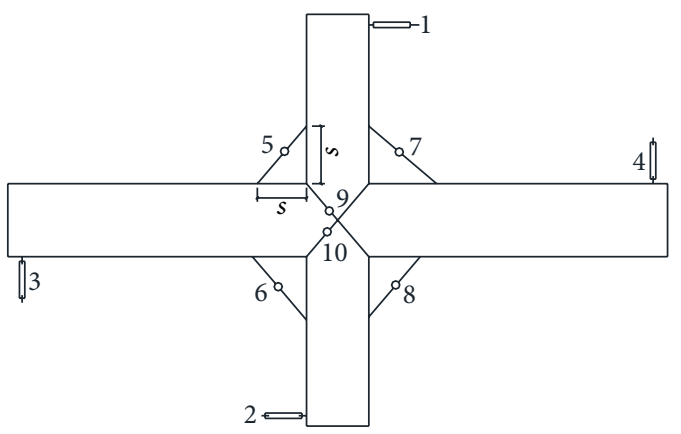

$\simeq$ Deformation instrument

$\multimap$ Dial indicator

FIGURE 9: Devices to test deformation.

As Figure 9 shows, column-to-beam rotation $\phi_{j}$ is determined from transducers 5 and 6 for the left side and from transducers 7 and 8 for the right side:

$$
\begin{gathered}
\phi_{c}^{l}=\arcsin \frac{\delta_{5,6} \sin 45^{\circ}}{s}, \\
\phi_{c}^{r}=\arcsin \frac{\delta_{7,8} \sin 45^{\circ}}{s} .
\end{gathered}
$$

Panel zone rotation is determined from transducers 9 and 10 shown in Figure 9 as

$$
\gamma=\frac{\sqrt{a^{2}+b^{2}} \cdot\left(\delta_{9}-\delta_{10}\right)}{2 \cdot a \cdot b} .
$$

The total story drift is determined from transducers 1 and 2:

$$
\Delta=\delta_{1}-\delta_{2}
$$

where $\delta_{1}, \delta_{2}, \delta_{5}, \delta_{6}, \delta_{7}, \delta_{8}, \delta_{9}$, and $\delta_{10}$ are the measured displacements.

As shown in Figure 11, story drift component caused by panel zone rotation can be derived as

$$
\begin{aligned}
\Delta_{\mathrm{pz}} & =0.5 H\left[\frac{\gamma_{1}(L-a)}{L}+\frac{\gamma_{2}(H-b)}{H}\right] \\
& =0.5 \gamma\left(2-\frac{a}{L}-\frac{b}{H}\right) H .
\end{aligned}
$$

Then, story drift component caused by connection rotation is given by

$$
\Delta_{c}=\Delta-\Delta_{\mathrm{pz}} \cdot
$$

Table 4 shows the total story drift, components caused by panel zone rotation, and connection rotation at yielding, limiting, and failure points. At failure point, the proportion of panel zone rotation accounting for the total story drift is $44 \%$, $67 \%, 84 \%, 73 \%$, and $66 \%$, respectively. The result indicated that the story drift component caused by panel zone rotation occupies a large percentage of the total deformation, which is consistent with the "weak joint" design.

A displacement ductility coefficient $(u)$ is defined as the ratio of the ultimate displacement $\left(\Delta_{u}\right)$ to the yielding displacement $\left(\Delta_{y}\right)$; namely, $\mu=\Delta_{u} / \Delta_{y}$, where $\Delta_{y}$ is yielding displacement according to the "energy method" shown in Figure 12 [26] and $\Delta_{u}$ is the ultimate displacement when the lateral load falls to $85 \%$ of the maximum lateral strength.

3.4. Strain Distribution. The strain measurement included steel strain, longitudinal bar strain, and stirrup hoop strain. Devices and measure points are shown in Figure 13. During the test, the strain distributions were similar. Thus, for ease of presentation, only one specimen is shown.

Figure 14 shows the measured values of the strain gauge A3 attached to the beam steel flange. During the early stages to yielding stage, small strain value under $1000 \mu \varepsilon$ was shown. It is indicated that the beam steel does not yield before the yielding point, which is also consistent with the test design intent.

Figure 15 shows the measured values of the strain gauge A2 attached to the column steel flange. At the early loading stage, the strain mainly consisted of axial compressive strain. The column longitudinal reinforcement sheared few parts of the axial compressive load. Then, under cyclic lateral loading, the column steel flange changed to a repeated state of tension and compression. The strain value did not reach to the yielding strain when the specimen yielded.

Figure 16 shows the measured principal strain values and direction of the strain rosettes B2 attached to the panel zone steel web. The strain value was small at the early loading stage and increased when the first panel inclined cracks were observed. The principal strain value showed that most of the steel web yielded when the specimen yielded, and the direction of principal strain varied from $26^{\circ}$ to $44^{\circ}$. Another phenomenon observed that the principal tensile strain value 


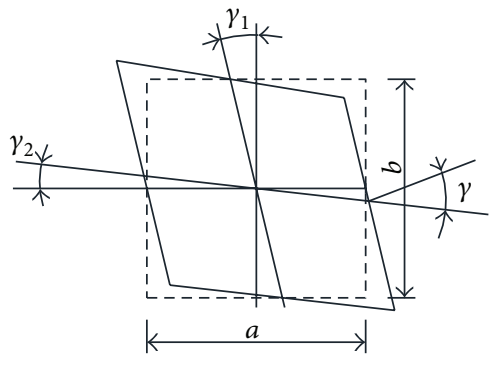

(a)

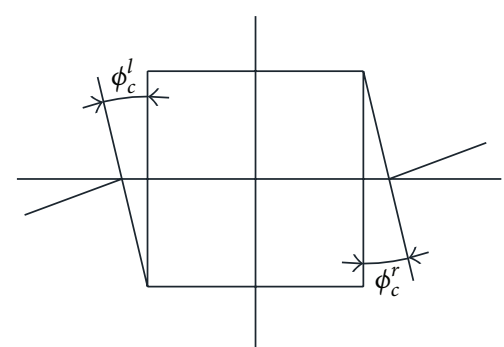

(b)

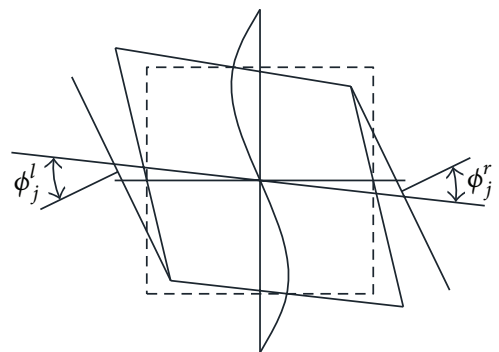

(c)

FIGURE 10: Definition of rotations at boundary of panel zone: (a) panel zone; (b) connection; (c) total joint.

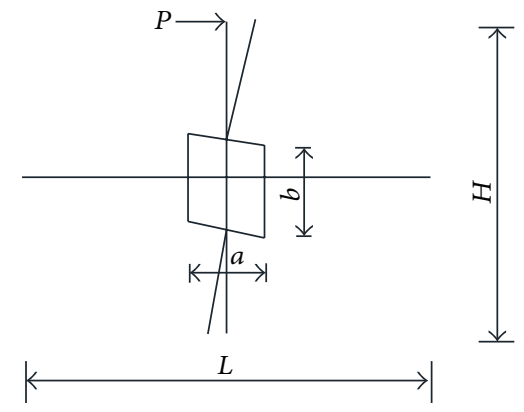

FIGURE 11: Story drift component caused by panel zone rotation.

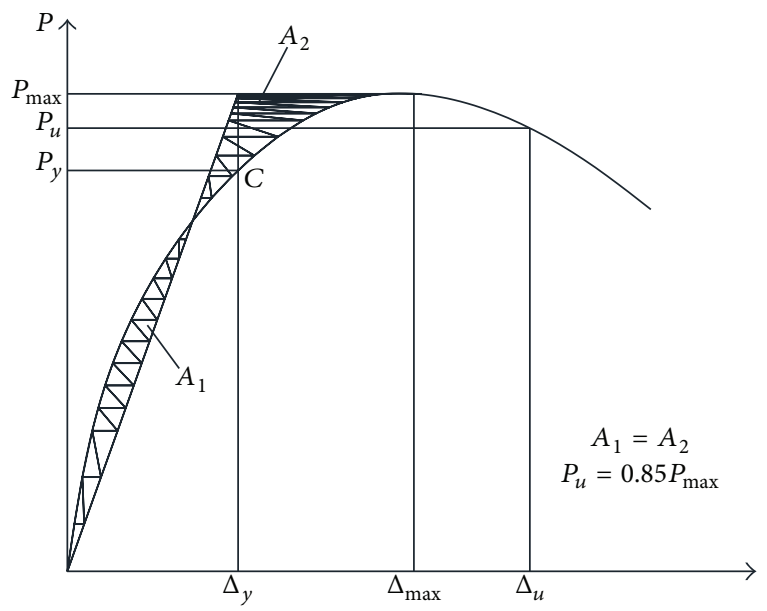

FIGURE 12: Definitions of yield point and failure point.

was always greater than that of the principal compressive strain.

Figure 17 shows the measured values of the strain gauge C10 attached to the hoop at core panel zone. At the early loading stage, the small strain value ranging from $200 \mu \varepsilon$ to $300 \mu \varepsilon$ was shown, which indicated that the shear was mainly subjected by concrete and steel web at core panel zone. At the yielding stage, the hoop was still at an elastic status. At the failure stage, the strain increased rapidly to the yielding strain.

Figure 18 shows the measured values of the strain gauge A6 attached to the steel flange box at core panel zone. Throughout the whole loading process strain value of steel flange box at core panel zone was small and at a repeated state of tension and compression. The result indicated that steel flange box was not a main part to bear the lateral shear, whose main roles were to transfer the tension and pressure effectively and to form a closed box restraining concrete and steel web.

3.5. Load-Displacement Curves. The recorded hysteretic curves of cyclic lateral load versus lateral displacement at the end of the beam for all specimens were collected (see Figure 9). The following features can be concluded by comparing the curves shown in Figure 19.

The joints possess several features of both steel joints and reinforced concrete joints, whose hysteresis curves are between the spindle and the $S$ form. Evident strength degradation was observed at every loading cycle after the specimens reached maximum strength. The pinching behavior, characterized by reduced stiffness at low force levels and considered undesirable for seismic design, was observed. The pinching was related mainly to the opening and closing of concrete cracks and gaps caused by shear distortion and crushing.

During the loading procedure, the specimens showed a hysteretic characteristic similar to steel frame joints. When the road reached the maximum load, the skeleton curve dropped, and then the skeleton curve eventually converge to a stable value. When the road reached the ultimate load, the specimens still possess a certain capability of bearing and deformation.

3.6. Ductility Capacity. Based on the hysteretic curve, the envelope curves of cyclic lateral load versus lateral displacement for the specimens were obtained (see Figure 20). The ductility values reflect the deformation capacity and potential for seismic performance, which is required to ensure ductile response and evaluate the deformation capacity.

Table 5 shows the characteristic value at yielding, limiting, and failure condition for all specimens. The average value of the displacement ductility coefficient was 3.59 in this test, which indicated that both specimens had good ductility under cyclic loading condition.

Under the same stirrup ratio, with the decrease of the axial compression ratio, the specimens have a better deformation capacity and strength decay comes more slowly. From 

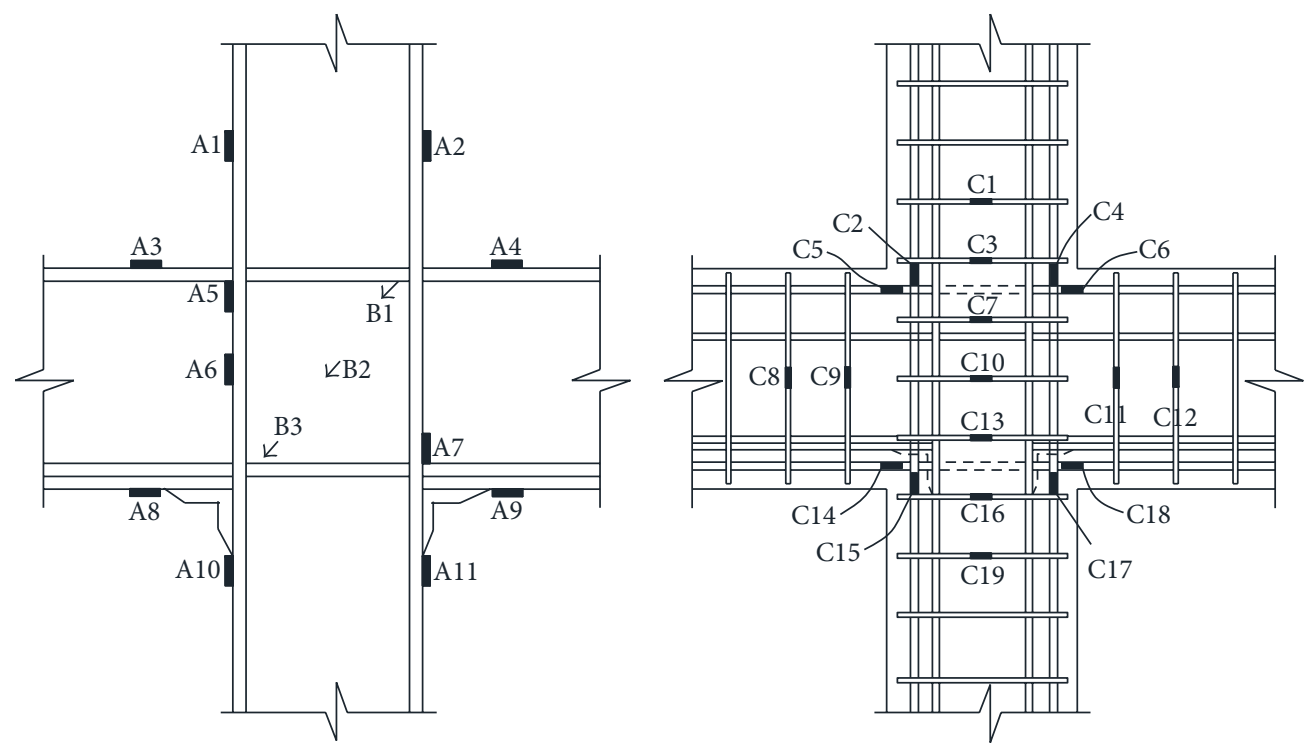

- Strain gage

$\measuredangle$ Three-dimensional rosette gauge

FIGURE 13: Strain measure points.

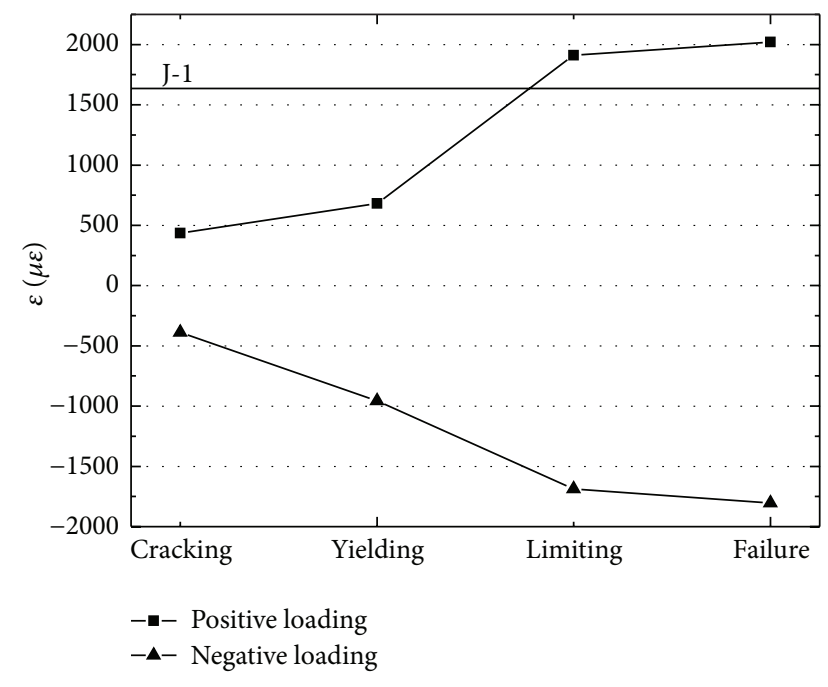

FIGURE 14: Strain of beam steel flange.

Table 5, for example, J-1, J-2, and J-3, as axial compression level increases from 0.2 to 0.6 , ductility coefficient drops from 3.87 to 3.53 .

From a comparison of $\mathrm{J}-3, \mathrm{~J}-4$, and $\mathrm{J}-5$, the ductility coefficient decreases with the increasing of concrete strength. However, it is not evident that using high strength concrete be inadaptable for concrete-encased composite frame joints. In general, the ductility is reduced unless a substantial amount of confinement is provided. The ductility coefficient value up to 2.92 was comparable to that with ordinary strength concrete, due to the steel web panel that contributed substantially to increasing the ductility.

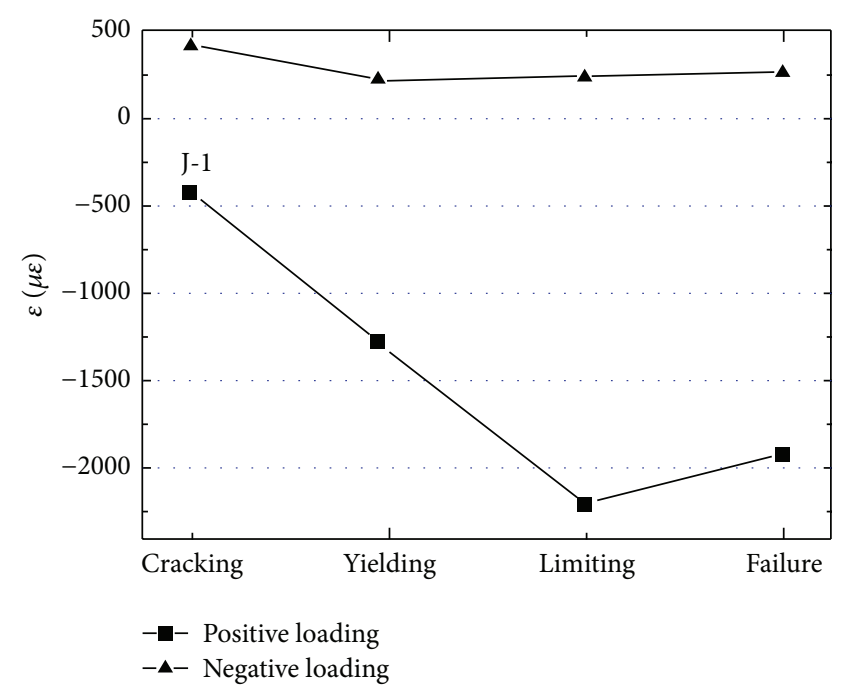

FIGURE 15: Strain of column steel flange.

3.7. Energy Dissipation Capacity. The energy dissipated during one loading cycle is defined as the area enclosed within the lateral load versus displacement curve, starting and ending with a zero displacement of the column end. In general, more energy is dissipated for the specimen with a bigger area enclosed.

The equivalent damping coefficient $h_{e}$ may be used to evaluate the energy absorption capacity while $h_{e}=$ $(1 / 2 \pi)\left(S_{\mathrm{ABC}} / S_{\mathrm{AOD}}\right)$, where $S_{\mathrm{ABC}}$ refers to the area enclosed within the hysteretic curve and $S_{\mathrm{AOD}}$ is the areas within triangles AOD, as shown in Figure 21, respectively [26]. 
TABLE 5: Characteristic value at yielding, limiting, and failure condition.

\begin{tabular}{|c|c|c|c|c|c|c|c|c|c|}
\hline \multirow[b]{2}{*}{ Number } & \multirow{2}{*}{$\begin{array}{c}\text { Cracking } \\
P_{\mathrm{cr}} \\
(\mathrm{kN})\end{array}$} & \multicolumn{2}{|c|}{ Yielding } & \multicolumn{2}{|c|}{ Limiting } & \multicolumn{2}{|c|}{ Failure } & \multirow[b]{2}{*}{$u$} & \multirow[b]{2}{*}{$h_{e}$} \\
\hline & & $\begin{array}{c}P_{y} \\
(\mathrm{kN})\end{array}$ & $\begin{array}{c}\Delta_{y} \\
(\mathrm{~mm})\end{array}$ & $\begin{array}{l}P_{\max } \\
(\mathrm{kN}) \\
\end{array}$ & $\begin{array}{l}\Delta_{\max } \\
(\mathrm{mm})\end{array}$ & $\begin{array}{c}P_{u} \\
(\mathrm{kN})\end{array}$ & $\begin{array}{c}\Delta_{u} \\
(\mathrm{~mm})\end{array}$ & & \\
\hline$J-1$ & 55.0 & 96.0 & 19.7 & 105.0 & 55.3 & 89.3 & 76.4 & 3.87 & 0.23 \\
\hline$J-2$ & 60.0 & 95.0 & 16.3 & 105.9 & 45.4 & 90.0 & 60.6 & 3.72 & 0.22 \\
\hline$J-3$ & 97.0 & 99.2 & 20.6 & 118.1 & 50.2 & 100.5 & 72.6 & 3.53 & 0.22 \\
\hline$J-4$ & 92.0 & 106.5 & 21.7 & 129.5 & 44.1 & 118.6 & 63.5 & 2.92 & 0.20 \\
\hline$J-5$ & 60.0 & 94.4 & 18.6 & 113.5 & 45.3 & 96.4 & 73.1 & 3.94 & 0.32 \\
\hline
\end{tabular}
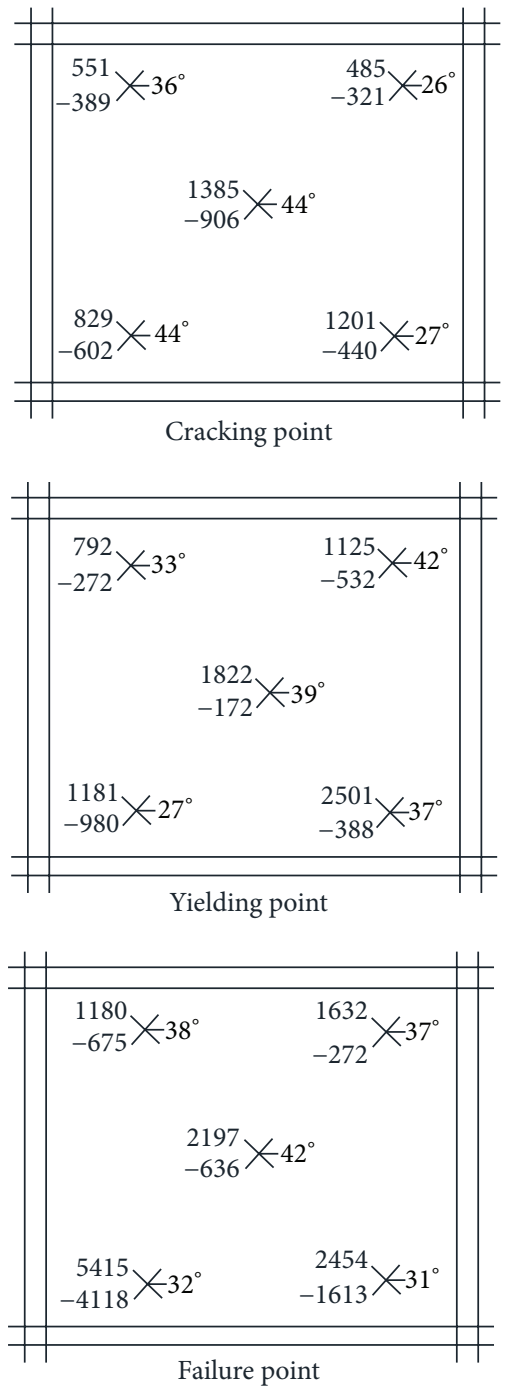

FIgURE 16: Strain of column steel web.

As expected, the energy dissipation capacity of the specimens stably increased with the increase in the load amplitude of the hysteresis loops up to the failure point. The final equivalent damping coefficients of specimens ranged from 0.22 to 0.32 in this test. Comparing this data to that of the reinforced concrete joint, it can be concluded that the energy dissipation

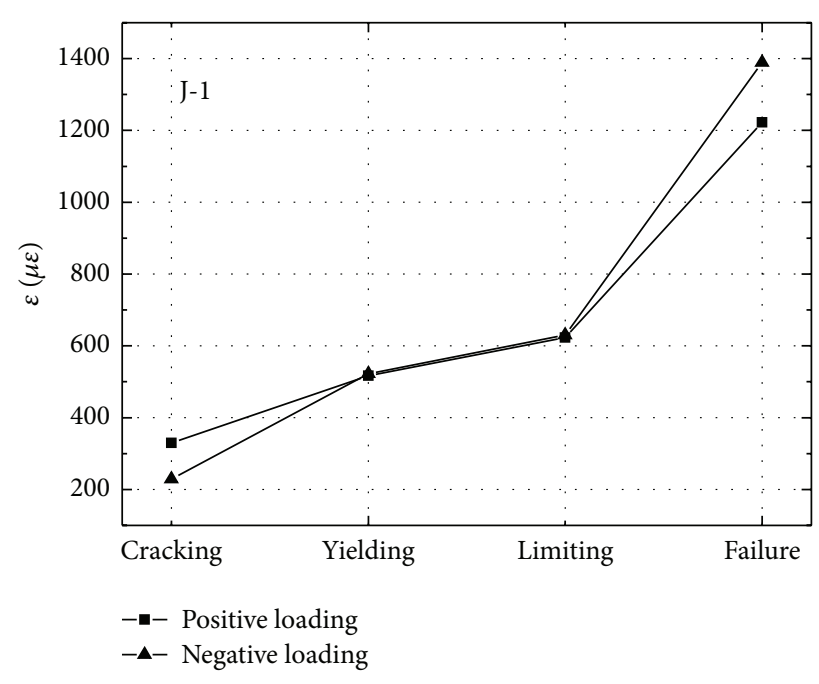

FIGURE 17: Strain of column hoop.

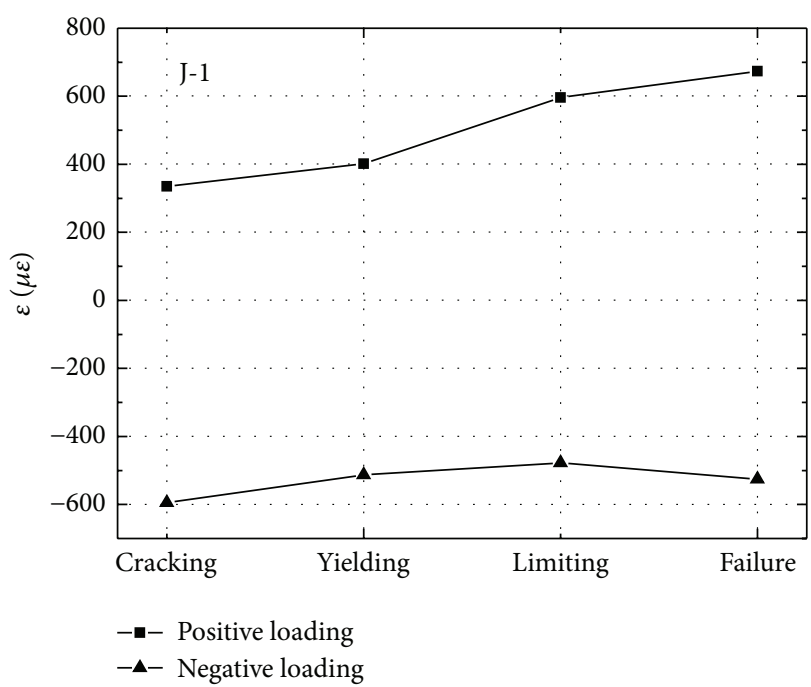

FIGURE 18: Strain of column steel flange box.

ability of this proposed internal-diaphragm joint is much higher than that of the reinforced concrete joint whose damping coefficient is about 0.1. Consequently, concreteencased composite frame joints with high strength concrete 

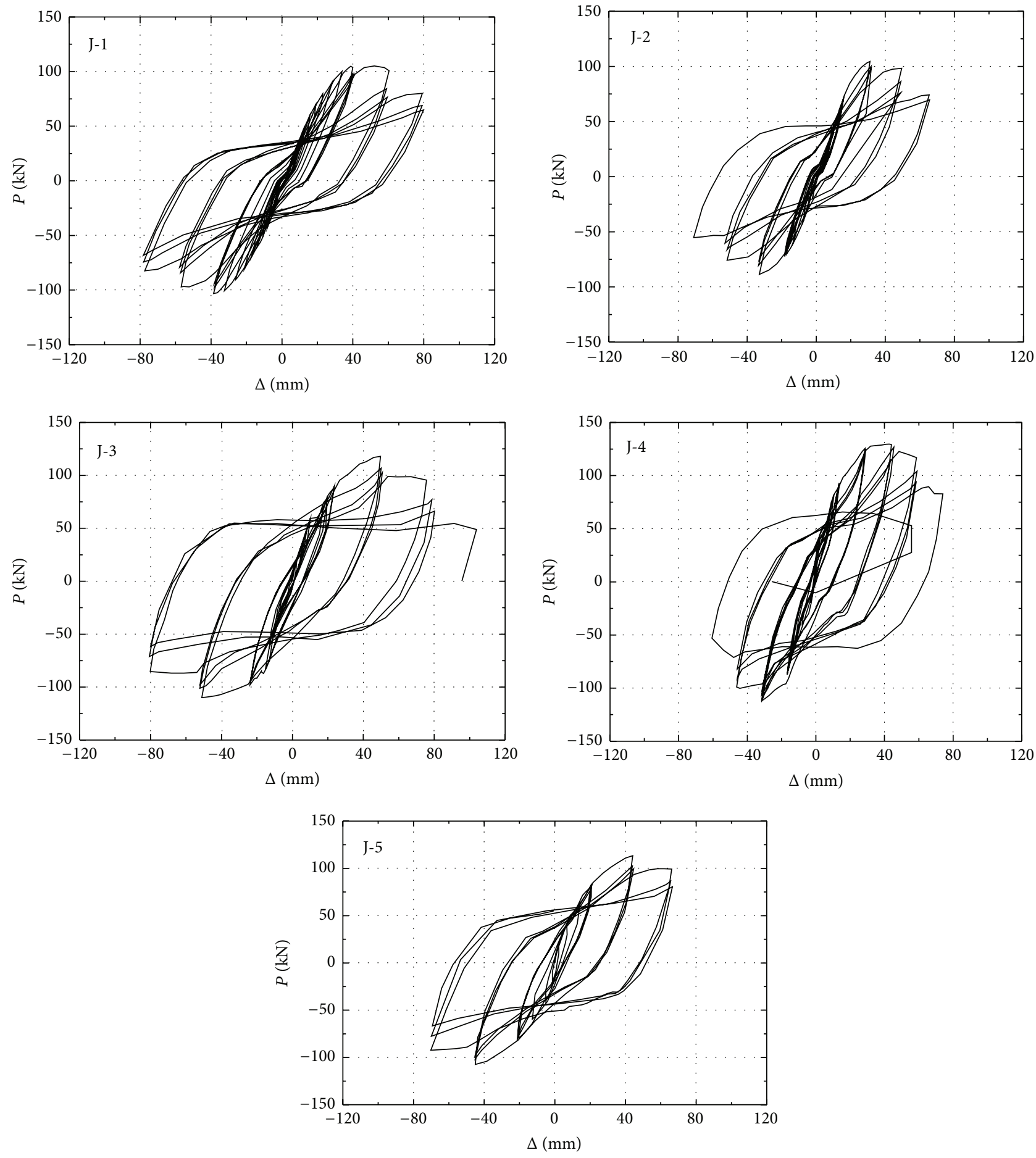

FIGURE 19: Hysteresis loops of specimens.

can offer sufficient energy dissipation capacity which makes it suitable for seismic applications in moment-resisting frames.

\section{Summary and Conclusions}

This paper describes a series of tests for concrete-encased composite frame joints with high strength concrete and presents discussions on the effects of different parameters (applied axial load ratio and concrete strength grade) on various characteristics of joint performance. From the test results, the following conclusions can be drawn.

The tested concrete-encased composite frame joints with high strength concrete were designed based on the weak joints approach. Although behaved in a manner with joint 


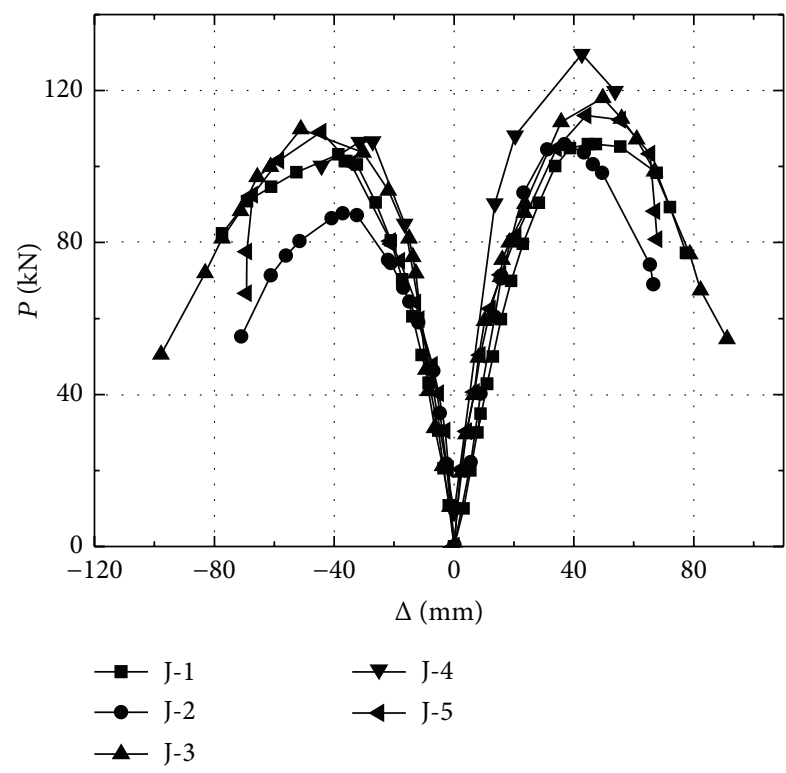

FIGURE 20: Force versus displacement skeleton curve.

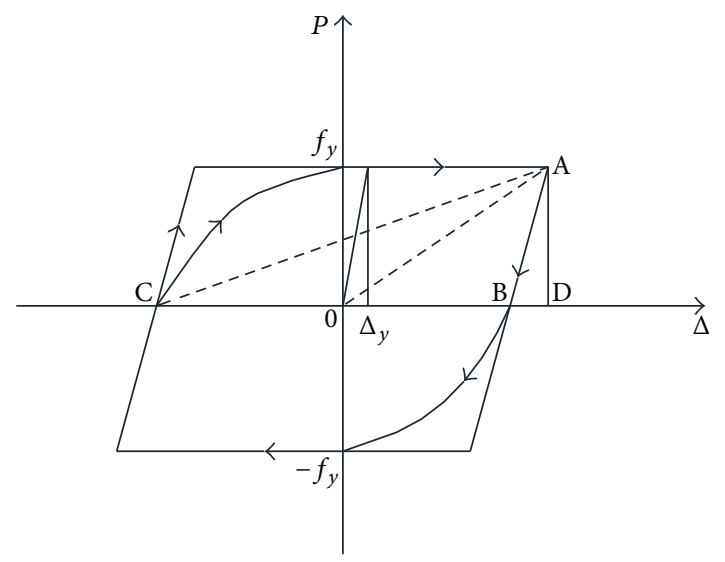

FIgURE 21: Hysteretic and energy dissipation capacity.

shear failure, all five test specimens showed a stable overall response to cyclic load reversals. The average value of displacement ductility reached 3.59. The joints had good structural performance with stable and ductile hysteresis behavior upon attaining their maximum strength with little deterioration of stiffness.

The total story drift is composed of components caused by panel zone rotation and connection rotation. Component caused by panel zone rotation occupies a large percentage of the total deformation especially at failure stage. The yielding of steel web is a gradual process from local to overall, and there is no evident inflection point on skeleton curve. The overall yielding of steel web at core panel zone can be considered as the sign announcing the yielding of specimen.

Using high strength concrete increased the joint strength. The high strength concrete had relatively little effect on the stiffness and ductility. Overall behavior of concrete-encased composite joints with high strength concrete was comparable to that with ordinary strength concrete, due to the fact that the steel web panel contributed substantially to increasing the ductility. This suggests that high strength concrete up to about $100 \mathrm{MPa}$ may be used in concrete-encased composite frames using similar criteria as for ordinary strength concrete.

The axial column load helped the joint by better mobilizing the outer part of the joint. With the increase of axial column load, the shear overstrength increased. On the other hand, the axial column load had an obvious influence on the ductility and energy-dissipating capacity of the specimens. The displacement ductility decreased as the axial load ratio increased. The equivalent damping coefficient decreased as the axial load ratio increased. This suggests that the axial column load cannot be neglected in design. The effect of the axial column load can be improved by providing enough transverse reinforcement and decreased spacing of the hoops, which will provide good confinement and ensure stability of the longitudinal rebars.

\section{Conflict of Interests}

The authors declare that there is no conflict of interests regarding the publication of this paper.

\section{Acknowledgments}

This research was funded by the National Natural Science Foundation of China (Grant no. 51108041) and Young and Middle-Aged Scientific and Technological Innovation Team Foundation of Hubei Province of China (Grant no. T201303), and their support is gratefully acknowledged.

\section{References}

[1] N. E. Shanmugam and B. Lakshmi, "State of the art report on steel-concrete composite columns," Journal of Constructional Steel Research, vol. 57, no. 10, pp. 1041-1080, 2001.

[2] J. Nie, M. Tao, Y. Huang, S. Tian, and G. Chen, "Research advances of steel-concrete composite structural systems," Journal of Building Structures, vol. 31, no. 6, pp. 71-80, 2010.

[3] G. G. Delerlein and H. Noguchi, "Overview of U.S.-Japan research on the seismic design of composite reinforced concrete and steel moment frame structures," Journal of Structural Engineering, vol. 130, no. 2, pp. 361-367, 2004.

[4] M. Begum, R. G. Driver, and A. E. Elwi, "Behaviour of partially encased composite columns with high strength concrete," Engineering Structures, vol. 56, pp. 1718-1727, 2013.

[5] C.-C. Chen and N.-J. Lin, "Analytical model for predicting axial capacity and behavior of concrete encased steel composite stub columns," Journal of Constructional Steel Research, vol. 62, no. 5, pp. 424-433, 2006.

[6] F.-Y. Liao, L.-H. Han, and Z. Tao, "Behaviour of composite joints with concrete encased CFST columns under cyclic loading: experiments," Engineering Structures, vol. 59, pp. 745-764, 2014.

[7] A. A. Marinopoulou, V. D. Balopoulos, and C. N. Kalfas, "Simulation of partially encased composite steel-concrete columns with steel columns," Journal of Constructional Steel Research, vol. 63, no. 8, pp. 1058-1065, 2007.

[8] C. Chen, C. Wang, and H. Sun, "Experimental study on seismic behavior of full encased steel-concrete composite columns," 
Journal of Structural Engineering, vol. 140, no. 6, Article ID 04014024, 2014.

[9] Antonius and I. Imran, "Experimental study of confined low, medium- and high-strength concrete subjected to concentric compression," ITB Journal of Engineering Science, vol. 44, no. 3, pp. 252-269, 2012.

[10] E. Ellobody, B. Young, and D. Lam, "Behaviour of normal and high strength concrete-filled compact steel tube circular stub columns," Journal of Constructional Steel Research, vol. 62, no. 7, pp. 706-715, 2006.

[11] J. R. Del Viso, J. R. Carmona, and G. Ruiz, "Shape and size effects on the compressive strength of high-strength concrete," Cement and Concrete Research, vol. 38, no. 3, pp. 386-395, 2008.

[12] A. R. Murthy, B. K. R. Prasad, and N. R. Iyer, "Estimation of fracture properties for high strength and ultra high strength concrete beams and size effect," International Journal of Damage Mechanics, vol. 22, no. 8, pp. 1109-1126, 2013.

[13] Y. K. Ju, J.-Y. Kim, and S.-D. Kim, "Experimental evaluation of new concrete encased steel composite beam to steel column joint," Journal of Structural Engineering, vol. 133, no. 4, pp. 519529, 2007.

[14] J. Fan, Q. Li, J. Nie, and H. Zhou, "Experimental study on the seismic performance of 3D joints between concrete-filled square steel tubular columns and composite beams," Journal of Structural Engineering, vol. 140, no. 12, Article ID 04014094, 2014.

[15] R. Realfonzo, A. Napoli, and J. G. R. Pinilla, "Cyclic behavior of RC beam-column joints strengthened with FRP systems," Construction and Building Materials, vol. 54, pp. 282-297, 2014.

[16] V. C. L. Gonzalez and G. Moriconi, "The influence of recycled concrete aggregates on the behavior of beam-column joints under cyclic loading," Engineering Structures, vol. 60, pp. 148154, 2014.

[17] M.-X. Tao, J.-S. Fan, and J.-G. Nie, "Seismic behavior of steel reinforced concrete column-steel truss beam hybrid joints," Engineering Structures, vol. 56, pp. 1557-1569, 2013.

[18] ACI Committee, Building Code Requirements for Structural Concrete (ACI 318-05) and Commentary (ACI 318R-05), American Concrete Institute, 2005.

[19] American Institute of Steel Construction, Load and Resistance Factor Design Specification for Structural Steel Buildings, AISC, Chicago, Ill, USA, 3rd edition, 1999.

[20] JGJ, “Technical specification for steel reinforced concrete composite structures," JGJ 138-2001, Architecture Industrial Press of China, Beijing, China, 2001 (Chinese).

[21] Architectural Institute of Japan, Standard for the Calculation of Steel-Reinforced Concrete Structures (AIJ-SRC), Architectural Institute of Japan, Tokyo, Japan, 2010, (Japanese).

[22] JGJ, “Technical specification for application of high strength concrete," JGJ/T 281-2012, Architecture Industrial Press of China, Beijing, China, 2012 (Chinese).

[23] China Standard Press, GB/T228.1-2010, Metallic MaterialsTensile Testing-Part 1: Method of Test at Room Temperature, China Standard Press, Beijing, China, 2011, (Chinese).

[24] Y. C. Wang, X. H. Dai, and C. G. Bailey, "An experimental study of relative structural fire behaviour and robustness of different types of steel joint in restrained steel frames," Journal of Constructional Steel Research, vol. 67, no. 7, pp. 1149-1163, 2011.

[25] A. Filiatrault, S. Pineau, and J. Houde, "Seismic behavior of steel-fiber reinforced concrete interior beam-column joints," ACI Materials Journal, vol. 92, no. 5, pp. 543-552, 1995.
[26] Architecture Industrial Press of China, JGJ101-96, Specification for Seismic Test Method, Architecture Industrial Press of China, Beijing, China, 1997, (Chinese). 

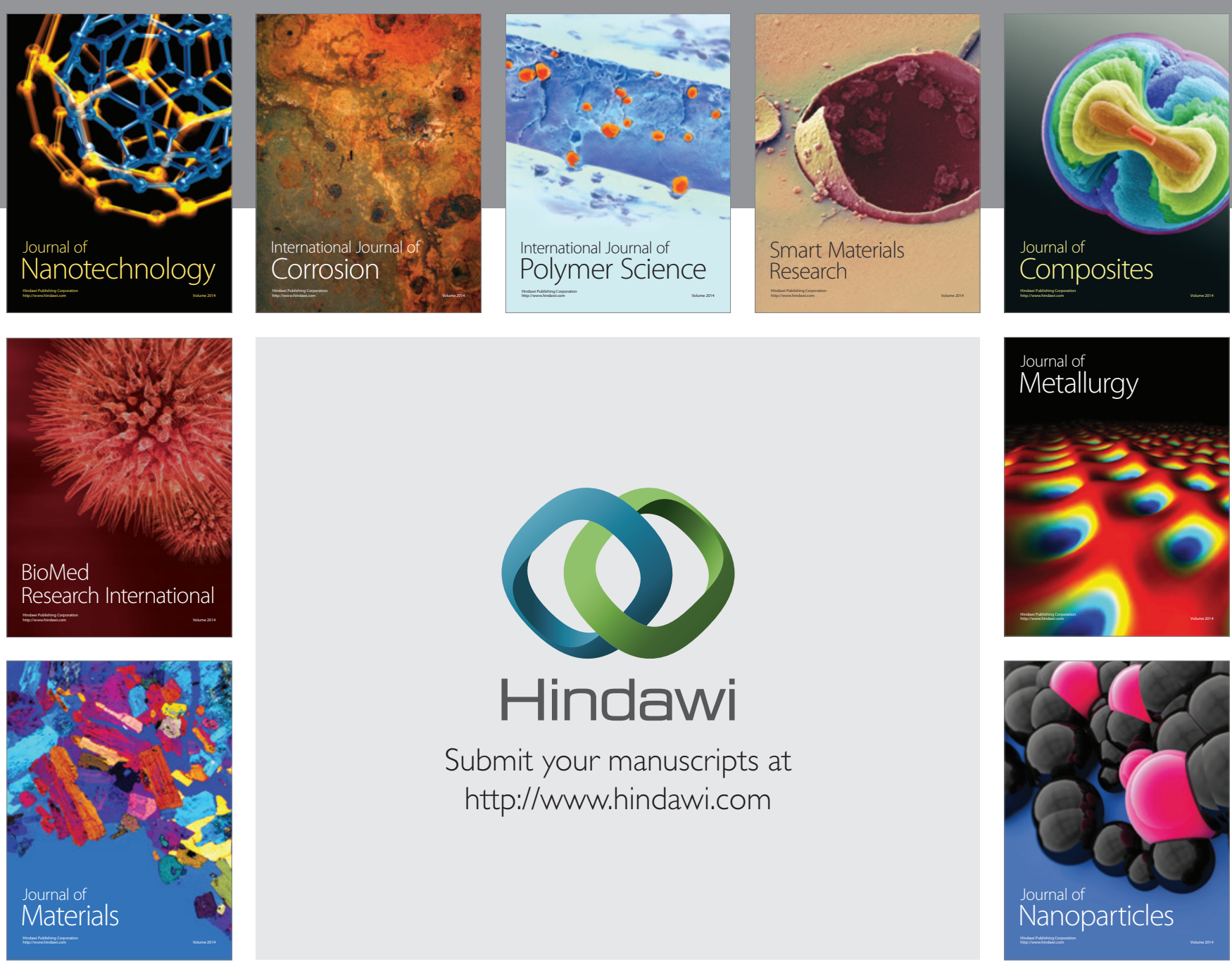

Submit your manuscripts at http://www.hindawi.com
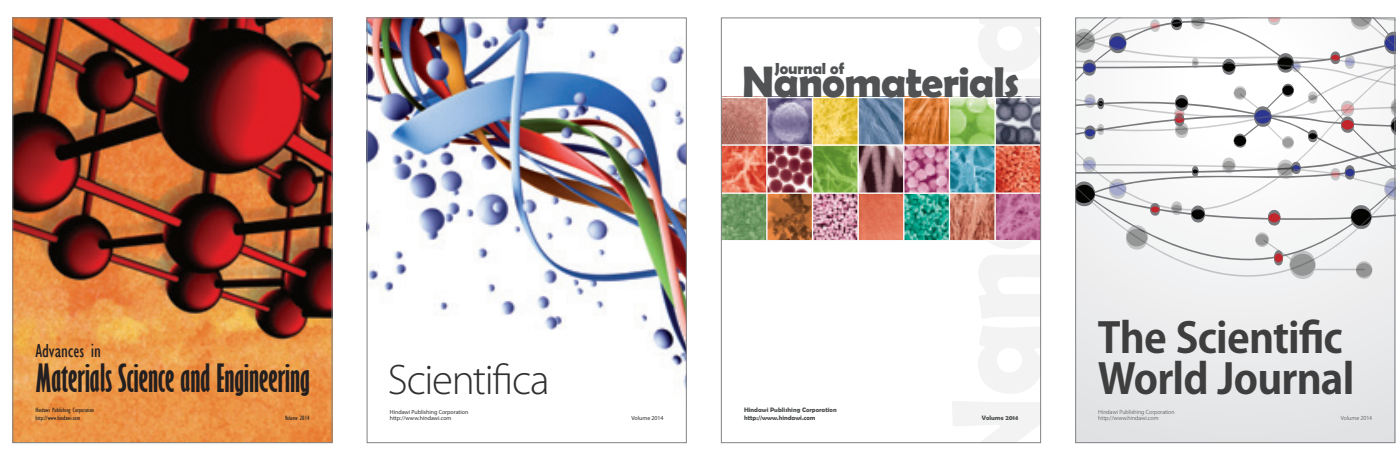

\section{The Scientific World Journal}
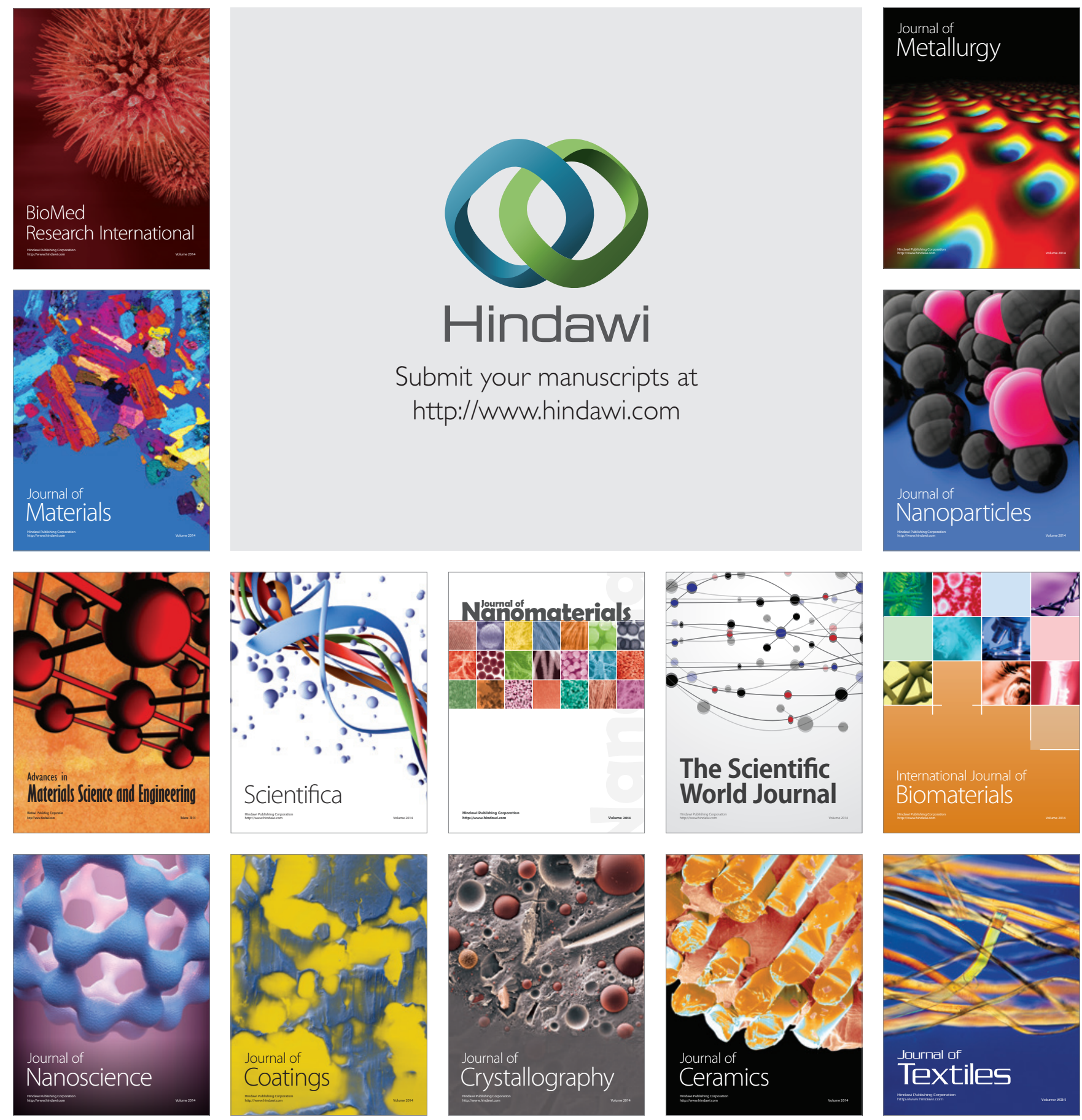